\title{
A CASE OF LINDAU'S DISEASE (CAPILLARY ANGIOMATOSIS)
}

BY

\author{
A. F. SLADDEN
}

DIRECTOR OF BECK LABORATORY, SWANSEA GENERAL AND EYE HOSPITAL

THE following case of Lindau's disease may be of special interest to ophthalmologists owing to its history.

Nearly twenty years ago Mr. Frank Thomas and the late Mr. George Coats published in the Trans. Ophthal. Soc. U.K. a note on "A peculiar Granuloma of the Retina " dealing with a youth having a retinal tumour which had necessitated removal of the affected eye.

In September, 1929, this same patient, W.J.J., now aged $3 i$ years attended Swansea General Hospital as a casualty, complaining of intense headache. At his first visit he was unwilling to be admitted; measures to relieve his state were taken, including lumbar puncture, and he went home but returned eleven days later with still worse headache, almost in coma and was admitted under Dr. Daniel Evans.

\section{Clinical Note}

The patient was a warehouseman and, apart from his early history as outlined by Thomas and Coats, he had fair health until 1921 when he began to suffer intermittently from headache.

In 1924 he had a fall, striking the back of the head, and subsequently the headaches became intensified, latterly causing an intolerable degree of pain. This became so devastating that finally he was compelled to seek medical assistance.

At the time of his admission to hospital there had been no vomiting, and no localising neurological signs were found nor were other physical signs of disease discovered. The right eye showed no papilloedema or retinal changes.

Lumbar puncture was again done; the two fluids were fully examined with the following results :

$$
\text { C.S.F. 10/9/29. C.S.F. 21/9/29. }
$$

$\begin{array}{lll}\text { Appearance } & \text { Clear, no clot } & \text { Clear, no clot } \\ \text { Cells } & \text { 0 per c.mm. } & 1 \text { per c.mm. } \\ \text { Protein } & 150 \text { milligrams } \% & 120 \text { milligrams } \% \\ \text { Globulin } & \text { Trace } & \text { Present } \\ \text { Glucose } & 66 \mathrm{mgr} . \% & 94 \mathrm{mgr} . \% \\ \text { Chloride } & 702 \mathrm{mgr} . & 805 \mathrm{mgr} . \% \\ \text { Gold curve } & 001221 \frac{1}{2} \frac{1}{2} 00000 & \frac{1}{2} \frac{1}{2} 1 \frac{1}{2} 1000000\end{array}$


The second C.S.F. was examined for urea content and showed 62 milligrams per cent. The earlier fluid and also the blood had been subjected to the Wassermann test with negative results. The urine showed no abnormalities.

A diagnosis of cerebral tumour was made provisionally. The patient rapidly became worse, hyperpyrexia followed and he died within a few hours of admission.

At this time and until after the post-mortem examination the earlier history of the man and the reasons for enucleation of the left eye were unknown.

Owing to the allegation of a blow on the head in 1924 the Coroner ordered a post-mortem examination.

\section{Summary of Post-mortem}

A well developed man. No evidence found of injury to scalp or skull. Left eye had been enucleated, cavity clean.

Head.-The left posterior fossa and left occipital space were definitely larger than the right, and the mid-line of the skull along the base and vault was displaced to the right. 'There was no sign of absorption of bone and the asymmetry appeared to be developmental.

The brain was congested and contained excess of fluid; the choroidal plexuses were oedematous; there was no meningitis.

Two small soft tumours were found in the cranial cavity, (1) A pedunculated growth, 1 inch in diameter, external to the left cerebellar lobe, sub-dural and pressing into this lobe so as to cause softening and yellow discoloration of the cerebellar tissue. Haemorrhage had occurred into this growth. (2) A smaller growth, $\frac{1}{3}$ inch in diameter, not pedunculated, in the posterior part of the right cerebellar lobe. It was soft in texture and whitish in colour.

Both tumours could be readily shelled out from the adjacent cerebellar tissue.

The remainder of the brain, save for some flattening of convolutions, appeared normal.

The evacuated left orbit contained no growth in or behind it.

Chest.-There was deep congestion of lungs and one haemorrhagic infarction was found. The heart was normal.

Abdomen.-All organs appeared normal except for the left kidney which contained two growths: (1) 1 inch diameter, in the cortex, projecting beyond the natural surface of the kidney. (2) $\frac{1}{4}$ inch diameter, also in cortical part of kidney but deeper.

These tumours were black in colour and on first view were thought to be melanomata. 
Histological examination of all the tumours, however, showed them to be angiomatous in character, and on mentioning the case to Mr. Frank Thomas the ancient history of the man, together with sections of the retinal tumour of 1911 and a copy of the note then published, were fortunately forthcoming.

Later, on discussing the matter with Dr. J. G. Greenfield, the writer was referred to publications on Lindau's disease and this

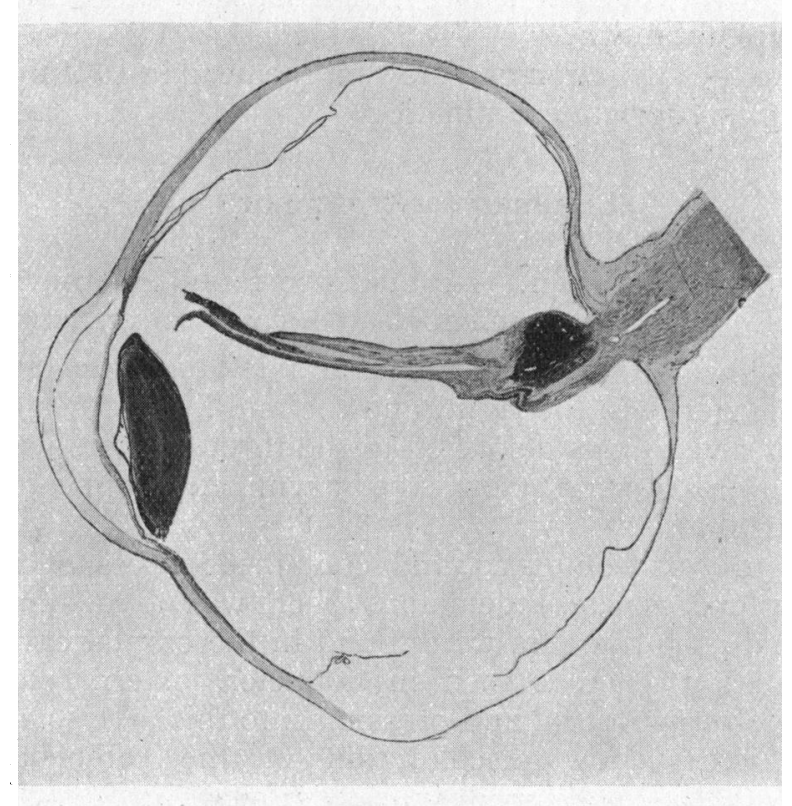

FIG. 1.

Eye, with retinal tumour.

case was recognised to be another instance of this recently-described syndrome.

For full details of the early history of the case readers are referred to Thomas and Coats's publication.

It is of interest; in view of the post-mortem findings in the kidney, that the original troubles directing the patient to hospital in 1910 were inability to micturate and headache, and these led to thorough ophthalmological examination and to the discovery of the retinal tumour. Increasing intra-ocular tension in due course compelled the loss of the left eye.

The late Mr. George Coats made a very detailed report on this eve but was unable to classify the tumour with any certainty, as can be seen in his report. 


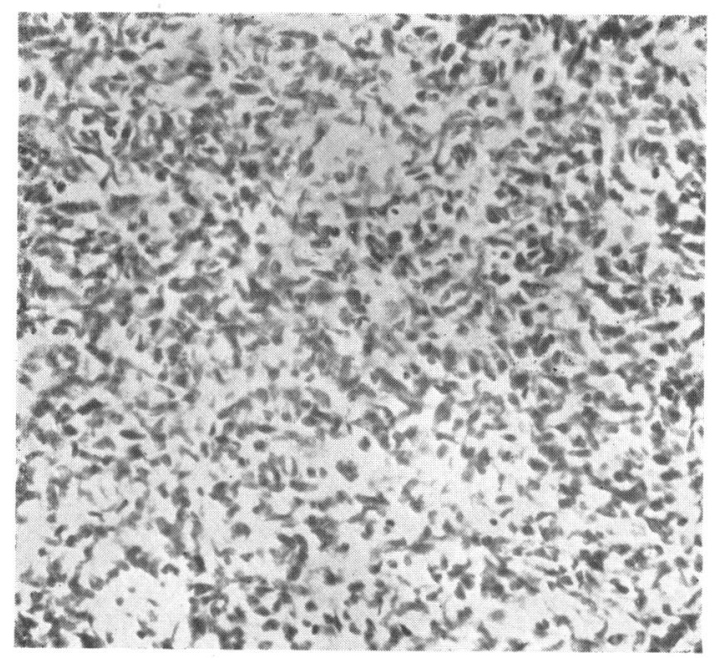

Retinal tumour, high-power.

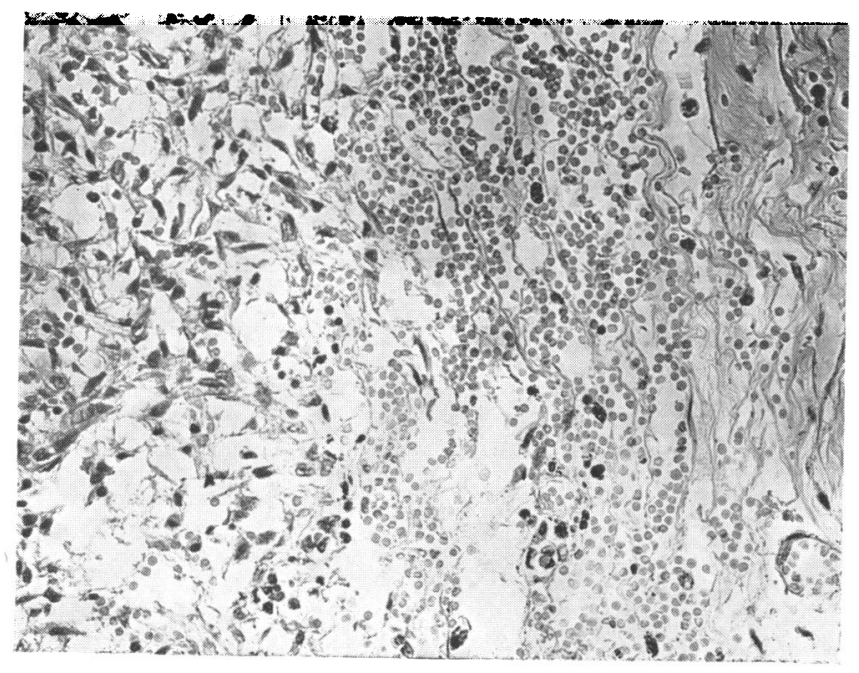

Fig. 3.

Left cerebellar tumour. 

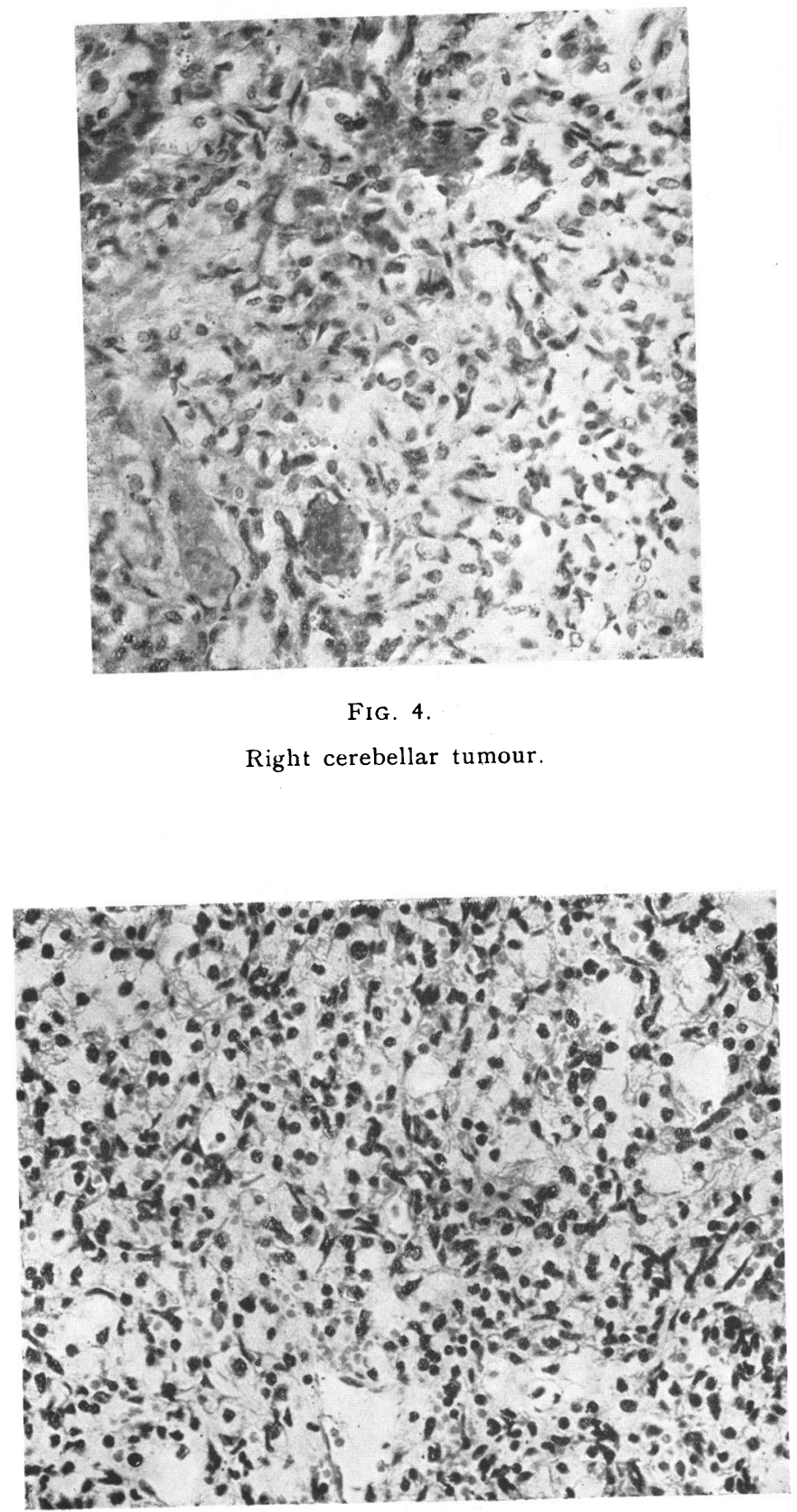

Fig. 5.

Left renal tumour. 
A further study of the original sections in the light of later developments makes it probable that the retinal tumour is to be classified as an angioma with unusually high proportion of endothelial cells and relatively slight formation of blood spaces.

The retinal growth was situated just to one side of the papilla (Fig. 1) and appears in sections at the base of a long stalk of detached retina. The growth is hightly cellular (Fig. 2) and although not capsulated it is fairly sharply defined.

It is in some areas highly vascular, the blood vessels usually showing well-formed walls but in a few instances appearing to be simple endothelial channels.

The constituent cells of this tumour are mostly elongated, with nuclei either ovoid or sickle-shaped, and closely packed, obscuring the supporting stroma. There are a few foci of polymorphonuclear inflammatory cells but for the most part the growth is not inflamed. The constituent cells are singularly devoid of evidence of mitosis such as one would expect tơ see in a true sarcoma.

The cerebellar and renal tumours (Figs. 3, 4, and 5) are much less densely cellular, much more vascular and their constituent cells much more pleomorphic than in the retinal tumour. Nevertheless, at the most concentrated areas the cells show frequently the ovoid or curved nuclei of those described in the retinal tumour, and the same absence of mitotic figures.

They show also numerous fibroblastic cells contributing to the structure of the walls of the blood spaces.

In the cerebellar and renal tumours the stroma is better defined, loose in texture and much infiltrated with red blood cells; wellformed blood channels are also numerous and apparently some breakdown of blood-cells has occurred with deposition of pigment.

The haemangiomatous nature of these tumours is best seen in the left cerebellar growth; its angiomatous cells, though less densely assembled show, on close study, essential identity with the constituent cells of the other tumours.

It appears that there may be considerable differences in the histology of tumours found in this syndrome.

The cerebellar tumours recorded in the literature are all haemangiomatous (Greenfield and Sargent), the renal tumours may be " clear-celled adenomata" instead of angiomata, $e . g$. , in the cases reported by Hadfield and by Shapiro renal adenomata were found, and Lindau in his original paper referred to 8 instances of hypernephroma out of a total of 275 cases of his syndrome. In Hadfield's case too, the pancreatic tumour was a polycystic condition arising, not from vascular structures but from dilatation of gland acini. 
The retinal tumours of this syndrome have, however, been described consistently as angiomata by all writers on the subject. (Vide von Hippel, Lindau, Paton and Williamson-Noble, Cushing and Bailey.)

The essential primary factor of Lindau's disease appears to be a congenital defect most frequently manifested in vasculár tisssue, and a practical point emphasised by many writers is the importance of intra-ocular examination for diagnosis when cerebellar tumours are concerned; it might well be borne in mind also when tumours of the kidney or pancreas are under consideration.

\section{Summary}

1. A case of Lindau's disease, with capillary angiomata of retina, cerebellum and kidney, is described.

2. The retinal growth had been removed 20 years previously.

3. The cerebral compression arising from the intra-cranial tumours became more manifest after a blow on the head 5 years before death.

4. There was some evidence of faulty development of the skull.

5. No history was obtained of similar conditions in the man's family.

The writer wishes to express his very cordial thanks to Dr. Greenfield for his valuable aid with micro-photography and in other directions, and to Mr. Frank Thomas for his help in elucidating the earlier ophthalmological history of the patient.

\section{REFERENCES}

Thomas, F. G., and Coats, G.-Trans. Ophthal. Soc. U.K., Vol. XXXI, p. $149,1911$.

Sargent, Percy, and Greenfield, J. G.-Brit. Jl. of Surgery, Vol. XVII, No. 65, p. 84, 1929.

Lindau, A.-Acta Pathol. et Microbiol., Scandinavica. Sup. 1, 1926. Acta Ophthal., Vol. IV, p. 193, 1927.

Cushing and Bailey.-Arch. of Ophthal., Vol. LVII, p. 447, 1928.

Hadfield, G.-Bristol Medico-chirurg. Jl., Spring, 1929. Sub-references in this paper to-

Schuback. -Zeitschr. f. d. ges. Neurol. u. Psychiatr., Berlin, ex. 359 u. 371, 1927.

Schubert.-Klin. Wochenschr., Berlin, Bd. VI, S. 821, 1927.

Weber. Parkes.-Proc. Roy. Soc. Med., Section of Neurol., Vol. XXII, No. 4, pp. 431-442, 1929.

Paton, Leslie, and Williamson-Noble.-Report of the Thirteenth International Ophthalmological Congress, p. 17, 1929.

Shapiro, P.-Arch. of Path., Vol. VIII, No. 6, p. 915, 1929. 